\title{
Article \\ Information Asymmetry, Ownership Structure and Cost of Equity Capital: The Formation for Open Innovation
}

\author{
Ade Imam Muslim ${ }^{1, *(D)}$ and Doddy Setiawan ${ }^{2}$ \\ 1 Department of Accounting, STIE Ekuitas, Jawa Barat 40124, Indonesia \\ 2 Department of Accounting, Faculty of Economics and Business, Universitas Sebelas Maret, \\ Surakarta 57126, Indonesia; doddy.setiawan@staff.uns.ac.id \\ * Correspondence: imam.muslim@ekuitas.ac.id
}

check for

updates

Citation: Muslim, A.I.; Setiawan, D. Information Asymmetry, Ownership Structure and Cost of Equity Capital: The Formation for Open Innovation. J. Open Innov. Technol. Mark. Complex. 2021, 7, 48. https://doi.org/10.3390/ joitmc7010048

Received: 27 December 2020

Accepted: 17 January 2021

Published: 29 January 2021

Publisher's Note: MDPI stays neutral with regard to jurisdictional claims in published maps and institutional affiliations.

Copyright: (c) 2021 by the authors. Licensee MDPI, Basel, Switzerland. This article is an open access article distributed under the terms and conditions of the Creative Commons Attribution (CC BY) license (https:// creativecommons.org/licenses/by/ $4.0 /)$

\begin{abstract}
Our study aims to investigate how information asymmetry and ownership structure affect cost of equity capital. For that purpose, we collected 246 issuers over 4 years for a total of 984 observations. By using panel data processing, we found that the information asymmetry we proxied through Price non-Synchronization and trading volume had an effect on the cost of equity capital. Our results also confirmed both Agency Theory and Pecking Order Theory. Both theories are in line with the conditions of the stock market in Indonesia. In addition, we found that institutional and foreign ownership structures also had an effect on the cost of equity capital. Furthermore, our results also confirmed Interest Alignment Theory and Entrenchment Theory. Our research is expected to contribute to the debate on the existence of information asymmetry and ownership structures in relation to the cost of equity capital. We also hope that it will be a valuable input for investors in considering their investment. Moreover, from the results of this study, investors can also consider foreign ownership or institutional ownership in determining their investment. In addition, stock market regulators in Indonesia can develop approaches to minimize information asymmetry and encourage foreign investors to invest in Indonesia.
\end{abstract}

Keywords: cost of equity capital; Indonesia; information asymmetric; ownership structure

\section{Introduction}

Our study aims to investigate how information asymmetry and ownership structure affect the cost of equity capital. Information asymmetry has become a concern of researchers and is a matter of debate among academics [1]. Ref. [2] argues that accounting information has an important role in the capital market. Previous studies have linked information asymmetry with the cost of equity capital. However, we found inconsistent results in a number of studies (see for example [1,3,4]). The results of [4] found that high information asymmetry can increase the risk premium, which in turn will increase the cost of equity capital. Studies conducted by [1] found that in an imperfect competition, information asymmetry affects the cost of equity capital. Ref. [5] analyzed the differences in the composition of information between public and private information. According to them, traders on the exchange who are not well informed tend to be at a disadvantage and consequently have few assets. This will result in a decrease in the price of securities and will ultimately increase the cost of equity capital.

In contrast to the above studies, research conducted by [6-11] found that increasing information asymmetry will actually reduce the cost of capital. Ref. [11] found that increasing knowledgeable investors in the economy can reduce the cost of equity capital. According to him, the decrease in the cost of equity capital was due to the combined effect of information asymmetry and average precision. Apart from being debatable, information asymmetry has long been a serious concern in the capital market [1]. For example, the Securities and Exchange Commission (SEC) enforces a Regulation Fair Disclosure (Reg FD). This regulation prevents companies from making disclosures to select investors 
and analysts. The SEC argued that selective disclosure could lead to information asymmetry. In Indonesia itself, disclosure regulations are regulated in Bapepam LK regulation No. 134/BL/2006. Through this provision, the issuer is obliged to submit a summary of important financial data. This regulation was issued in order to minimize information asymmetry and provide convenience for investors. In addition, this regulation is in line with the open innovation paradigm, in which every company must convey information openly to the public; one of the ways the can happen is through information technology channels. Research conducted by [12] found that there is a positive relationship between open innovation and company performance.

Regarding ownership structure, previous studies state the importance of institutional ownership in determining company value and protecting investors, increasing transparency [13], and reducing the cost of equity capital [14-16]. In addition, managerial ownership will reduce the cost of equity capital. Managers expect more compensation by reducing the cost of equity capital from external financing [17]. Ref. [18] argue that when directors and managers own company shares, it will encourage managers to have a mentality as company owners. This is in contrast with the study conducted by [17]. Their study found that institutional ownership has a significant effect and will increase the cost of equity capital.

These studies were conducted in a foreign context. However, research in local contexts such as in Indonesia has not been widely carried out. Refs. [19,20] call for the importance of doing more studies into the local context to see the extent to which corporate governance mechanisms work. Our research seeks to fill that gap. Our focus is on how information asymmetry and ownership structures can affect the cost of equity capital and provide empirical evidence from capital markets in Indonesia. The capital market in Indonesia is a developing and interesting capital market to study. Referring to [21], developing capital markets are interesting to study because they can attract the attention of foreign investors; it can also reduce portfolio risk through diversification. In addition, conventional governance [22] and weak protection of minority shareholders [23] are interesting research themes to study and relate to, with the factors that influence them.

This study is important in order to measure the cost of equity capital. The high cost of equity capital will result in low performance and even the rejection of potential investments [24]. In addition, high information asymmetry causes difficulties for companies to understand the real conditions of the market, especially in cases where the capital market reflects irrelevant information and managers will make more conservative estimates [25].

This study is expected to contribute in several ways. First, this study contributes to the debate on information asymmetry by clarifying the role of asymmetry and ownership structure in influencing the cost of equity capital. Second, it provides empirical evidence for the development of the information asymmetry literature and cost of equity capital. Third, it contributes to the development of literature related to the economic consequences of ownership structures by providing evidence from the Indonesian capital market-how ownership structures affects the cost of equity capital. Finally, we hope that this study will have implications for investors in considering their investment and their expected rate of return.

This study is organized into four parts. The first is an introduction, which describes how important this research is and what previous studies have produced. Second, we examine related variables through the related literature. Third, we describe the research sample and methods of analysis for these variables. Fourth, we present the results of research and discussion. Finally, we present conclusions and opportunities for further research.

\section{Literature Review}

We explain the relationship between variables through four theories. The first is agency theory and pecking order theory to describe the relationship between information asymmetry and the cost of equity capital. The other two theories, Interest Alignment Theory 
and the Entrenchment Theory, are used to describe the relationship between ownership structure, and cost of equity capital.

\subsection{Agency Theory}

Our research focus is on how investors consider the expected rate of return through the level of their investment. Therefore, we choose agency theory as a theory that can explain the relationship of information asymmetry with the cost of equity capital. Agency theory holds that there is an agent relationship between principals and agents [26]. Both the agent and the principal are in a position to maximize profits. If the agent has more information than the principal, it will lead to information asymmetry. This information asymmetry will result in monitoring, bonding, and even residual costs. Monitoring costs are costs that arise because the principal must monitor the agent so that they do not carry out deviant practices that can cause losses to the principal. Bonding costs are costs incurred by the agent to ensure the principal receives compensation if an agent's action is detrimental to the principal. Finally, there is the possibility of creating a residual cost. Costs are borne by principals as a result of decreasing their welfare. This is caused by any actions of the agent which are detrimental to the principal. Thus, increasing information asymmetry will increase the cost of equity capital.

\subsection{Pecking Order Theory}

The second theory we chose to explain the relationship between information asymmetry and the cost of equity capital is the Pecking Order Theory. Pecking Order Theory was popularized by [27]. The postulation of this theory is that the cost of financing will increase with increasing information asymmetry. Information asymmetry arises when companies issue sources of funding in the form of equity (share issuance). At the time of this share issuance, investors perceive managers to have more information about the company and value shares higher than the value of the company, and managers take advantage of that valuation. Therefore, investors will underestimate the price of the shares issued. In other words, high information asymmetry and low stock prices implies a high cost of equity capital.

\subsection{The Relationship between Asymmetric Information, Capital Structure, and Cost of Equity Capital}

This discussion is paramount to see how companies choose their capital structure in relation to the condition of information asymmetry and cost of equity capital. Ref. [28] investigated companies in the United States in determining their capital structure. The results found that companies will avoid issuing debt securities if the market knows little information about the company. In other words, if there is information asymmetry in the capital market, companies tend to delay the issuance of debt securities. In line with the pecking order theory [27], if a company chooses to issue stock securities in conditions of high information asymmetry, it will ultimately decrease stock prices and increase the cost of equity capital.

\subsection{The Interest-Convergence Thesis and Entrenchment Theory}

The relationship between ownership structure and cost of equity capital can be explained by two theories. First is the Interest Alignment Theory and the second is Entrenchment Theory. Alignment Theory introduced the convergence of interests thesis. The convergence of interests thesis argues that ownership structure will minimize the cost of equity capital. The second is the Entrenchment Theory. This theory argues that the ownership structure will actually increase the cost of equity capital.

\subsection{Ownership Structure Based on Interest Alignment Theory}

The assumption of this thesis is that greater ownership of capital will help maximize firm value. In addition, this thesis can also be explained through stewardship theory. 
In view of stewardship theory, managers will act and carry out tasks to satisfy all company partners. This will have an impact on the corporate governance system so that it will lead to public interest. In the end, the presence of managers and shareholders will reduce information asymmetry and the cost of equity capital [29]. Regarding foreign ownership, Ref. [30] argues that foreign ownership is more vigilant in protecting their interests than domestic investors. Referring to [29], foreign ownership also demands more good governance practices, so that the health level of the company is better maintained. In addition, foreign ownership can convince other company partners and give confidence to potential investors. In the end, this will lead to a low cost of equity.

\subsection{Ownership Structure Based on Entrenchment Theory}

Entrenchment Theory assumes that excessive control from blockholders will in fact lead to conflict between minority and majority shareholders. Ref. [31] provided an example, in which this conflict will also increase if blockholders actually collaborate with managers to secure their interests. Regarding foreign ownership, in the context of poor governance and high risk, foreign shareholders actually encounter obstacles in terms of language and space [32]. In addition, they also experience information asymmetry problems [29]. In the end, the foreign ownership structure will increase the cost of equity capital. A study conducted by [33] found that a large divergence of ownership controls has a positive effect on the cost of equity capital. In line with this study, Ref. [34] found that companies with significant institutional investment in their ownership structure require high capital costs.

\subsection{The Relationship between Asymmetric Information and Cost of Equity Capital}

Previous studies have shown that information asymmetry is related to the cost of equity capital. Ref. [3] examined information asymmetry among investors in affecting the cost of equity capital. His research involves perfect markets and imperfect markets. The results [3] of the study found that in a perfectly competitive market, information asymmetry has a positive relationship with the cost of equity capital. Meanwhile, the study conducted by [4] examines the relationship between information asymmetry, diversification, and the cost of equity capital. The results of the [4] study found that although information asymmetry does not affect the cost of equity capital, it does affect the risk factor premium. Based on the results of this study, we suspect that information asymmetry is positively related to the cost of equity capital, and companies with a high level of asymmetry tend to also have a high cost of equity capital.

Hypothesis 1 (H1). Ceteris paribus, Information asymmetry can increase the cost of equity capital.

\subsection{The Relationship between Ownership Structure and Cost of Equity Capital}

Previous studies have shown that the ownership structure that indicates controlling share ownership interacts in determining the cost of equity capital [23,35-37]. This concentration of ownership can help alleviate agency problems between owners and managers which in turn will reduce the cost of equity capital. Research conducted by [38] investigates the corporate governance mechanism of US companies in relation to the cost of equity capital. The results of the study found that companies with good governance tend to have a low cost of equity capital. Other studies also support the same results. An example is a study conducted by [39] on companies in the US from 1992 to 2002. Their results support the hypothesis that good governance is associated with a low cost of equity capital.

Hypothesis 2 (H2). Ceteris paribus, companies with a high level of institutional ownership have a low cost of equity capital.

Hypothesis 3 (H3). Ceteris paribus, companies with a high level of public ownership have a low cost of equity capital. 
Hypothesis 4 (H4). Ceteris paribus, companies with high levels of foreign ownership have a low cost of equity capital.

Studies conducted by $[40,41]$ found that large companies characterized by high total assets generally have a high level of disclosure, resulting in low information asymmetry and cost of equity capital. Based on this, we formulate the following hypotheses:

Hypothesis 5 (H5). Ceteris paribus, for companies with a high level of total assets tend to have asymmetry and low cost of equity, compared to companies with low total assets.

Hypothesis 6 (H6). Ceteris paribus, for companies with high levels of total assets, their ownership structure has a significant effect on the cost of equity capital.

Studies conducted by [29,42] show that ROA represents the level of risk, so it can be used as an appropriate predictor of the cost of equity capital. A high rate of return represents low risk, and of course has an asymmetry and also a low cost of equity. Based on this, we formulated the following hypotheses:

Hypothesis 7 (H7). Ceteris paribus, for companies with high profits (positive), tend to have asymmetry and a low cost of equity, compared to companies with low profits (negative).

Hypothesis 8 (H8). Ceteris paribus, for companies with high (positive) profits, their ownership structure has a significant effect on the cost of equity capital.

According to [41], leverage reflects the level of the company's financial risk. Studies conducted by [43-45] provide evidence that the higher the leverage, the higher the cost of equity capital. Based on this, we formulated the following hypotheses:

Hypothesis 9 (H9). Ceteris paribus, companies with high leverage levels tend to have asymmetry and a high cost of equity, compared to companies with low leverage levels.

Hypothesis 10 (H10). Ceteris paribus, companies with high levels of leverage, their ownership structure has a significant effect on the cost of equity capital.

\section{Materials and Methods}

\subsection{Sample}

We used a sample of all companies listed on the Indonesia Stock Exchange for the periods of 2016-2019. The total number of listed companies until 2019 is 726 issuers. We classify these companies based on their industry. Furthermore, we filtered according to the data measurement requirements used in each research variable and consistently submitted financial reports for 3 consecutive years. Based on that, we obtained 246 issuers, so our total observations were 984 . Table 1 represents the distribution of the research sample by industry. 
Table 1. Distribution of firm-year observations by industry and year. Source: Processed data.

\begin{tabular}{cccccccc}
\hline Industry & $\mathbf{2 0 1 6}$ & $\mathbf{2 0 1 7}$ & $\mathbf{2 0 1 8}$ & $\mathbf{2 0 1 9}$ & \multicolumn{2}{c}{ Observation } \\
\cline { 6 - 8 } & & & & & Total & $\mathbf{\%}$ \\
Manufacture & 35 & 35 & 35 & 35 & 140 & 14 \\
Consumer Goods & 31 & 31 & 31 & 31 & 124 & 13 \\
Infrastructure & 21 & 21 & 21 & 21 & 84 & 9 \\
Mining & 8 & 8 & 8 & 8 & 32 & 3 \\
Property & 42 & 42 & 42 & 42 & 168 & 17 \\
Trading & 75 & 75 & 75 & 75 & 300 & 30 \\
Agriculture, Plantation, and Forestry & 14 & 14 & 14 & 14 & 56 & 6 \\
Other & 20 & 20 & 20 & 20 & 80 & 8 \\
Total & 246 & 246 & 246 & 246 & 984 & 100 \\
\hline
\end{tabular}

The research sample is dominated by trade deposits. Almost $30 \%$ of our observations are made on issuers belonging to the trading industry. The sectors that have the least amount are agriculture, plantation, and forestry, with only $6 \%$ that we can collect from these issuers.

\subsection{Research Model}

In an effort to answer our proposed hypotheses. We formulated the following research model:

Model 1:

$\operatorname{COEC}_{i t}=\beta_{0}+\beta_{1} A S Y M_{i t}+\beta_{2} S_{I Z E_{i t}}+\beta_{5} L E V_{i t}+\beta_{6} R O A_{i t}+\beta_{7} \operatorname{LogSales}_{i t}+\beta_{8}$ RTVOL $_{i t}+\epsilon_{i t}$

Model 2:

$$
\operatorname{COEC}_{i t}=\beta_{0}+\beta_{1} O W N_{i t}+\beta_{2} \text { SIZE }_{i t}+\beta_{3} L E V_{i t}+\beta_{4} R O A_{i t}+\beta_{5} \operatorname{LogSales}_{i t}+\beta_{6} R T V O L_{i t}+\epsilon_{i t}
$$

The first model is formulated to find out how information asymmetry affects the cost of equity capital and answers the first hypothesis. The second model is formulated to find out how the ownership structure affects the cost of equity capital.

\subsection{Measurement of Asymmetric Information}

We measure information asymmetry using two proxies. First is VOLTRADE. Following [46] we used VOLTRADE as a proxy for information asymmetry. The higher the trading volume, the lower the information asymmetry. Trading volume is defined as the square root of the shares traded divided by the shares outstanding. VOLTRADE is formulated as follows:

$$
\text { VOLTRADE } E_{i t}=\frac{\sqrt{\text { Tradeble Shares }}}{\text { Listed Shares }}
$$

The second measure is PNSY or price non-synchronization $\left(1-R^{2}\right)$. Ref. [47] argued that low $R^{2}$ reflects the poor quality of the information environment, as well as a large degree of asymmetry. To measure information asymmetry using PNSY or price non-synchronization, we used variations in stock returns, where the level of variation in stock returns can be broken down into two components, first, market rate variations that measure systematic variation; and second, company-specific information or price non-synchronization, this can be reflected in $\left(1-R^{2}\right)$. We obtained $R^{2}$ from the following regressions:

$$
r_{i t}=\alpha_{i}+\beta_{1} R_{m t}+\varepsilon_{i t}
$$

where $r_{i t}$ is the return of firm $i$ at time $t, R_{m t}$ is the market return at time $t$.

\subsection{Measurement of Cost of Equity Capital}

The rate of return expected by investors is represented in the cost of equity capital [48]. Our research uses the CAPM model. CAPM is a measurement of the cost of equity capital 
that is widely used by researchers [49]. Apart from measuring the cost of equity capital, CAPM is also useful, especially in evaluating portfolio performance [50]. The CAPM model was introduced by [51] and used by [52]. Mathematically, this model is formulated as follows:

$$
\operatorname{COEC}_{i t}=R_{f}+\beta \times\left(R_{m}-R_{f}\right)
$$

where $R_{f}$ is a risk-free investment that we propose with BI 7 Day. $\beta$ is a systemic risk that cannot be eliminated through diversification by investors. We compute $\beta$ through the slope of the regression of the stock's monthly returns and market returns. Rm is the return market. We use the composite stock price index return or IHSG as a proxy for market return.

\subsection{Measurement of Ownership Structure}

Referring to the [41] study, there are six proxies that can be used to measure ownership structure. First is ownership concentration. One of the measurements of ownership concentration is the Herfindal Index. Many previous researchers used this proxy to measure ownership concentration $[53,54]$. Ownership concentration is the sum of the squares of the percentage of shares owned by the top three shareholders.

The second measure is institutional ownership. This ownership is the percentage of shares owned by institutional investors. Institutions in this case can be in the form of financial institutions, social security, mutual funds, investment companies and other forms of companies. The third measure is state ownership. State ownership is the percentage of shares owned by the state. It is indicated that state ownership can increase the cost of equity capital. Referring to the studies of [31,55], state ownership in a company can encourage a high cost of equity capital because it tends to increase corruption and political costs. The fourth measure is managerial ownership. This ownership is the percentage of shares owned by managers in the company. A previous study has shown that managerial ownership can mitigate information asymmetry and reduce the cost of equity capital (see [56]). The fifth measure is foreign ownership. Foreign ownership is measured by the percentage of ownership in the company. Previous studies have shown that foreign ownership can reduce the cost of equity capital (see [29,30]). The last is family ownership. In this study, we focus on measuring the structure of institutional ownership, public ownership, and foreign ownership. The ownership structure dominates in the ownership structure of the entity.

\subsection{Measurement Control Variable}

Our research involves companies listed on the Indonesia Stock Exchange for the periods of 2016-2019. To control for specific company characteristics, such as firm size, debt structure, return volatility and earnings levels, we use control variables consisting of SIZE, LEV, RTVOL and ROA, and LogSales. SIZE is the natural logarithm of total assets. Studies by $[41,57]$ used SIZE as a control variable. SIZE can also capture the information environment or information asymmetry $[58,59]$. LEV is leverage, the ratio between total debt and total assets. Referring to [41], LEV reflects the level of corporate financial risk. A number of studies provide evidence that the higher the leverage, the higher the cost of equity capital [43-45]. RTVOL is the monthly stock return volatility of each issuer. We measure volatility through the standard deviation of each issuer's monthly stock returns. ROA is a return on assets. Referring to [29,42], ROA represents the level of risk, so that it can be used as an appropriate predictor of the cost of equity capital. ROA is a comparison between the current year's profit and total assets. Finally, LogSales is the logarithm of total sales.

\section{Results and Discussion}

First, we performed a descriptive analysis through mean, maximum value, minimum value, standard deviation, and correlation between each variable. The purpose of this analysis is to complete our main test, and to see the extent to which these variables differ 
from their mean, the maximum and minimum values of each variable. The following table represents the results of descriptive and correlational statistics between variables.

Based on Table 2 above, we obtain information that the mean COEC measured using the CAPM model is 0.180192 , with a maximum value of 4.61 and a minimum value of 0.00 . The standard deviation is 0.287494 . In addition to the cost of equity capital, we obtain information that the mean information asymmetry measured using Voltrade and PNSY is 0.026 and 0.85 , respectively. The maximum values are 0.218 and 1.00 , respectively. The minimum values are 0.003 and 0.078 , respectively. The standard deviation is 0.020 and 0.16 , respectively. We also obtain information on the mean ownership structure measured using institutional, public, and foreign ownerships of $0.70,26.89$, and 0.41 , respectively. The maximum values are $0.99,1.17$, and 0.99 , respectively. The minimum values are $0.179,0.002$, and 0.001 , respectively. Standard deviation is $0.28,0.18$, and 0.18 , respectively. Other information related to the mean of control variables SIZE, LEV, ROA, LogSales, and RTVOL are $6.44,0.45,0.038,6.16$, and 0.133 , respectively. The maximum values are $7.98,4.5,0.92,8.02$, and 4.44, respectively. The minimum values are $4.12,0.00,-1.216$, 1.81 , and 0.00 , respectively. The standard deviations are $0.79,0.295,0.12,0.805$, and 0.313 , respectively. Table 3 provides information on correlational relationships between variables. Information asymmetry that we measured using Voltrade and PNSY, respectively, has a correlational relationship with the cost of equity capital that we measure using CAPM of 0.31 and -0.28 . The ownership structures that we measured using institutional, public, and foreign ownerships has a correlational relationship with a cost of equity capital of $-0.03,0.04$, and 0.0057 .

Table 2. Descriptive Statistics.

\begin{tabular}{|c|c|c|c|c|c|c|c|c|c|c|c|}
\hline & Capm & Inst Own & Pub Own & Fore Own & Voltrade & Pnsy & Lev & Size & Roa & Rtvol & Logsales \\
\hline Mean & 0.180 & 0.706 & 0.268 & 0.410 & 0.025 & 0.859 & 0.454 & 6.442 & 0.038 & 0.127 & 6.162 \\
\hline Median & 0.109 & 0.737 & 0.229 & 0.388 & 0.017 & 0.921 & 0.429 & 6.498 & 0.027 & 0.080 & 6.291 \\
\hline Max & 4.610 & 0.998 & 1.170 & 0.998 & 0.218 & 1.000 & 4.503 & 7.985 & 0.921 & 4.440 & 8.028 \\
\hline Min & 0.000 & 0.179 & 0.002 & 0.001 & 0.003 & 0.078 & 0.000 & 4.129 & -1.216 & 0.000 & 1.808 \\
\hline Std. Dev. & 0.287 & 0.181 & 0.178 & 0.282 & 0.023 & 0.165 & 0.295 & 0.732 & 0.122 & 0.313 & 0.805 \\
\hline Skewness & 9.338 & -0.562 & 0.905 & 0.366 & 2.686 & -1.691 & 6.406 & -0.370 & -1.470 & 11.43 & -0.586 \\
\hline Kurtosis & 135.1 & 2.571 & 4.042 & 1.955 & 15.77 & 6.220 & 84.50 & 3.036 & 36.70 & 147.6 & 4.465 \\
\hline
\end{tabular}

Table 3. Pearson Correlation.

\begin{tabular}{|c|c|c|c|c|c|c|c|c|c|c|c|}
\hline & Capm & Inst Own & Pub Own & Fore Own & Voltrade & Pnsy & Lev & Size & Roa & Rtvol & Logsales \\
\hline Capm & 1.000 & & & & & & & & & & \\
\hline Instown & -0.033 & 1.000 & & & & & & & & & \\
\hline Pubown & 0.043 & -0.888 & 1.000 & & & & & & & & \\
\hline Foreown & 0.005 & 0.416 & -0.332 & 1.000 & & & & & & & \\
\hline Voltrade & 0.310 & 0.042 & -0.072 & -0.045 & 1.000 & & & & & & \\
\hline Pnsy & -0.287 & 0.055 & -0.078 & -0.063 & 0.136 & 1.000 & & & & & \\
\hline Lev & 0.031 & -0.012 & 0.037 & 0.021 & -0.054 & 0.026 & 1.000 & & & & \\
\hline Size & -0.083 & -0.166 & 0.178 & 0.016 & -0.514 & -0.062 & 0.051 & 1.000 & & & \\
\hline Roa & -0.055 & 0.106 & -0.091 & 0.130 & -0.010 & 0.008 & -0.138 & 0.048 & 1.000 & & \\
\hline Rtvol & 0.613 & 0.010 & -0.008 & 0.051 & 0.264 & 0.027 & 0.056 & -0.045 & -0.056 & 1.000 & \\
\hline Logsales & -0.100 & 0.020 & -0.010 & 0.159 & -0.342 & -0.024 & 0.177 & 0.775 & 0.153 & -0.067 & 1.000 \\
\hline
\end{tabular}

Note: Capm is a measurement of the cost of equity capital. Voltrade and Pnsy are measures of information asymmetry. Instown, Pubown, Foreown are ownership structures that represent institutional ownership in the form of blockholders, public ownership below 5 percent, and foreign ownership. Size, Lev, Roa, Logsales, and Rtvol represent firm-specific control variables.

Based on this data, we analyze that the correlational relationship between voltrade and the cost of equity capital is positive. According to our expectations, the higher the voltrade, the higher the cost of equity capital. The results of this study are in line with the studies of $[3,46]$. We found a negative relationship between price non-synchronization (PNSY) and cost of equity capital in our study. Ref. [47] argued that a low $R^{2}$ reflects the poor quality of the information environment, as well as a high level of asymmetry. The higher the price non-synchronization (PNSY) number indicates a low $R^{2}$ and of course the poor quality of information and high information asymmetry. Through this measurement, our study proves that the higher the price non-synchronization (PNSY), the lower the cost of equity 
capital. The ownership structure that we propose through institutional, public, and foreign ownership structures in general has very little relationship with the cost of equity capital. Institutional ownership or blockholders of more than $5 \%$ can reduce the cost of equity capital. On the other hand, foreign and public ownerships in our study have a positive relationship with the cost of equity capital.

\subsection{Information Asymmetry and Cost of Equity Capital}

We perform tests to answer the first hypothesis. We do this test to determine the extent to which information asymmetry can increase the cost of equity capital. First we did the Breusch Pagan LM Test, and the Hausman test to choose the right model. Second, we analyzed the test results to obtain the right model. The results of the Breusch Pagan LM Test and the Hausman test obtained a significance of 0.000 . Based on the result, we chose the Fixed Effect model as the appropriate model.

Based on Table 4 we were informed that our main variable asymmetry of information that we measure using Voltrade reflect the significance of 0.0000 , significant at the level of $1 \%$ with a positive direction. Meanwhile, PNYS shows that the significance of 0.0000 is significant at the $1 \%$ level in the negative direction. Almost all of our control variables showed no significance, except for the monthly stock return volatility. RTVOL shows the significance of 0.0000 or significance at the $1 \%$ level in the positive direction.

Table 4. Panel Data Testing with Fixed Effect Model.

\begin{tabular}{ccc}
\hline & Predictive Sign & Fixed Effect Model \\
\hline \multicolumn{1}{c}{ Dependent Variable: Cost of Equity Capital (CAPM) } \\
\hline Constant & + & $0.929452(0.2299)$ \\
Voltrade & + & $18.29687(0.0000)^{* * *}$ \\
PNSY & - & $-0.587424(0.0000)^{* * *}$ \\
Size & + & $-0.147271(0.2431)$ \\
Lev & - & $-0.051665(0.3515)$ \\
ROA & + & $0.054057(0.2674)$ \\
LogSales & + & $0.040260(0.5094)$ \\
RTVOL & & $0.366074(0.0000)^{* * *}$ \\
F Statistic & & $3.355885(0.000)^{* * *}$ \\
Adjusted R Square & & 0.376778 \\
Observation & 983 \\
\hline Note: Figures in the parentheses are t-statistics, except for Breusch Pagan LM Test, Hausman Test, which are \\
$p$-values. ${ }^{* * *}$ significant at 0.01 level $(p<0.01)$.
\end{tabular}

The results of this study are consistent with our expectations, that information asymmetry has a significant effect on the cost of equity capital. In this case, asymmetry can increase the cost of equity capital. These results confirm the studies conducted by $[1,3,4]$, and agency theory and pecking order theory put forward by [26,27]. Our results also confirm the first hypothesis that information asymmetry can increase the cost of equity capital.

Agency theory assumes that information asymmetry arises from information gap between principals and agents. This information gap occurs because one party has more information than the other party. Investors can act as principals and company management as agents. When the principal or agent has more information, information asymmetry will arise. Regarding information asymmetry, pecking order theory also assumes that a company that focuses on the capital structure of share issuance will have a high level of information asymmetry, and further drive the high cost of equity capital.

Our results indicate that the conditions of the Indonesian capital market are in line with both the agency theory and the pecking order theory. The high level of information asymmetry and the low protection of investors have boosted the high cost of equity capital in Indonesia. In addition, Indonesia is noted to have a high cost of equity capital compared to other ASEAN countries (see [60]). 
The RTVOL control variable fits our expectations. Return volatility greatly affects the cost of equity capital, and high return volatility can increase the cost of equity capital. This is consistent with [61] that capital markets in developing countries have high volatility, high information asymmetry, high transaction costs, and lack of protection for investors. Our results provide evidence that firm size is not a variable that can control the effect of information asymmetry on the cost of equity capital. These results are not in line with the studies of $[41,57]$. The sample we analyzed provides evidence that the size of the company that we propose using the natural logarithm of total assets has no effect on the cost of equity capital. Therefore, we did additional testing by dividing the sample by the size of the company. The leverage control variable in our study also found evidence that it does not affect the cost of equity capital. The results of this study are contradictory to the studies of [43-45]. Therefore, we also perform additional tests by framing the sample based on the level of leverage.

Our results provide paramount empirical implications. First, in an effort to address the problem of information asymmetry and the high cost of equity capital in the Indonesian and perhaps global capital markets, we recommend using a tit-for-tat approach. The tit-fortat approach is based on retaliation, good is rewarded with kindness, and bad is rewarded with malignance. In the context of agency problems, when the company's performance is poor, the principal as an investor will punish the agent in the form of selling shares. Conversely, when the company's performance is good, the principal as an investor will give an award in the form of buying shares or holding them from being sold. Through this tit-for-tat approach, agency problems between the principal and the agent will be minimized because the agent will maintain their performance.

Second, the company must determine the trade-off in its capital structure. The tradeoff balances the selection of sources of capital from debt and equity. The high level of choice of sources of capital from debt will risk bankruptcy. Likewise, choosing a source of capital from equity will increase the cost of equity capital. It is important in this case that the company determines the trade-off between debt and equity in a balanced manner.

\subsection{Ownership Structure and Cost of Equity Capital}

We conducted tests to answer the third, fourth, and fifth hypotheses. This test is conducted to determine the extent to which ownership structure affects the cost of equity capital. First, we did the Breusch Pagan LM Test, and the Hausman test to choose the right model. Second, we analyzed the test results to obtain the right model. The results of the Breusch Pagan LM Test and Hausman test obtained a significance of 0.000 and 0.0031 . Based on the results, we chose the Fixed Effect model as the appropriate model.

Based on Table 5, we obtain information that our main variables, institutional ownership and foreign ownerships, have a significant effect on the cost of equity capital that we measured using the CAPM model. The significance of institutional ownership is 0.0151, or is significant at the $1 \%$ level, and the significance of foreign ownership is 0.0761 , or significant at $10 \%$. In this test, we obtain information on the direction of the coefficient in which institutional ownership has a positive direction, which means that the ownership structure can increase the cost of equity capital. This is in line with the theory of Entrenchment Theory. The high cost of equity capital caused by excessive control from blockholders will actually cause a conflict between minority and majority shareholders, thus increasing the cost of equity capital. Our research supports the results of [31]. 
Table 5. Ownership structure and cost of equity capital using the CAPM model.

\begin{tabular}{ccc}
\hline & Predictive Sign & Fixed Effect \\
\hline & Dependent Variable: Cost of Equity Capital (CAPM) \\
\hline Constant & - & $1.624040(0.0768)^{* *}$ \\
Inst_Own & - & $0.566434(0.0151)^{* * *}$ \\
Pub_Own & - & $0.117470(0.5186)$ \\
Fore_Own & - & $-0.265066(0.0761)^{* *}$ \\
Size & + & $-0.205788(0.1896)$ \\
Lev & - & $-0.096137(0.1467)$ \\
ROA & + & $0.071428(0.5579)$ \\
LogSales & + & $-0.067386(0.4472)$ \\
RTVOL & & $0.119306(0.0114)^{* * *}$ \\
F Statistic & & $5.298265(0.000000)^{* * *}$ \\
Adjusted R Square & 0.589512 \\
Observation & 426 \\
\hline
\end{tabular}

Note: Figures in parentheses are t-statistics, except for Breusch Pagan LM Test, Hausman Test, which are $p$-values. ** significant at 0.1 level $(p<0.10)$, ${ }^{* *}$ significant at 0.01 level $(p<0.01)$.

Meanwhile, foreign ownership has a negative coefficient direction. This means that the higher the foreign ownership, the lower the cost of equity capital. The results of this study support the Interest Alignment Theory. Our results are also in line with the results of [30], in which foreign ownership is more vigilant in protecting their interests than domestic investors. Ref. [29] also argues that foreign ownership demands good governance practices, so that the health level of the company is better maintained. In the end, it will lower the cost of equity capital.

Our results also confirm the second and fourth hypotheses that we proposed, where institutional ownership and foreign ownership have an effect on the cost of equity capital. Our results prove that public ownership has no effect on the cost of equity capital. Our results also prove that we stand between the two theories we support, Entrenchment Theory and Interest Alignment Theory.

Entrenchment Theory assumes that ownership structure can increase the cost of equity capital, while Interest Alignment Theory assumes that ownership structure can reduce the cost of equity capital. In the contexts of Indonesia, the ownership structure consists of family, institutional, foreign, or public ownership. The stock market conditions in Indonesia support both theories. For the Indonesian stock market, the presence of foreign ownership can reduce the cost of equity capital. Unfortunately, foreign ownership in Indonesia has not been dominant. Only certain companies have foreign ownership structures (e.g., Astra International, Nippon Indosari Corpindo, Jakarta, Indonesia). In addition, the conditions of the Indonesian stock market also prove that the institutional ownership structure, or blockholders, will actually increase the cost of equity capital. The presence of this ownership can create conflicts between shareholders. This conflict will create high monitoring costs and ultimately increase the cost of equity capital. Unfortunately, blockholder ownership of more than 5\% in Indonesia is found in almost all companies listed on the Indonesia Stock Exchange. This condition is what we identify as an indicator of the high cost of equity capital in Indonesia compared to other ASEAN countries.

\subsection{Sensitivity Analysis}

In an effort to extend the main test, we performed additional testing. First, we divided the companies based on their total assets. Companies with total assets greater than the average were grouped in the first group, and companies below the average were in the second group. This test was carried out to see the extent to which large or small companies can affect the cost of equity capital. We performed this test to answer the fifth and sixth hypotheses. Second, we divided the companies based on their profits. Companies in the first group are companies with positive profits and the second group are companies with negative profits. We performed this test to answer the seventh and eighth hypotheses. 
Third, we also divided the companies based on their level of leverage. Leverage reflects the level of the company's financial risk, the higher the leverage the higher the cost of equity capital. Companies with leverage levels above the average we group into the first group, and companies below the average we grouped into the second group. We performed this test to answer hypotheses nine and ten.

For this purpose, we compiled the following model:

Model 3:

$$
C O E C_{i t}=\beta_{0}+\beta_{1} O W N_{i t}+\beta_{2} A S Y M_{i t}+\beta_{3} S I Z E_{i t}+\beta_{4} L E V_{i t}+\beta_{5} R O A_{i t}+\beta_{6} \text { LogSales }_{i t}+\beta_{7} R T V O L_{i t}+\epsilon_{i t}
$$

where COEC is the cost of equity capital that we measure using the CAPM model. OWN is an ownership structure that we proxied through institutional ownership, public and foreign ownership. ASYM is an information asymmetry that we proposed through Voltrade, while PNSY, SIZE, LEV, ROA, LogSales, and RTVOL were control variables. The following Table 6 represents the results of these additional tests. These tests are based on ordinary least square analysis.

Table 6. Additional testing based on the size of the company.

\begin{tabular}{cccc}
\hline & Predictive Sign & Company above Average & Company below Average \\
\hline & Dependent Variable: Cost of Equity Capital (CAPM Model) \\
\hline Constant & & $1.182222(0.1461)$ & $1.126982(0.0000)^{* * *}$ \\
Voltrade & + & $2.699815(0.1225)$ & $-0.396720(0.7132)$ \\
PNSY & + & $0.057727(0.8159)$ & $-0.629106(0.0000)^{* * *}$ \\
Inst_Own & - & $-0.643516(0.3281)$ & $0.000939(0.4082)$ \\
Pub_Own & - & $-0.862899(0.2094)$ & $0.000503(0.6250)$ \\
Fore_Own & - & $-0.096452(0.5170)$ & $-0.000253(0.5933)$ \\
Size & - & $-0.058091(0.6272)$ & $-0.034229(0.3466)$ \\
Lev & + & $0.044141(0.6996)$ & $0.078255(0.1776)$ \\
ROA & - & $0.205577(0.4762)$ & $0.217691(0.1034)^{* *}$ \\
LogSales & + & $-0.031243(0.7250)$ & $-0.044457(0.0506)^{*}$ \\
RTVOL & + & $4.095659(0.0000) * * *$ & $0.023452(0.5101)$ \\
F Statistic & & $120.3676(0.000000) * * *$ & $11.47022(0.000000)^{* * *}$ \\
Adjusted R Square & & 0.864958 & 0.344650 \\
Sample & & 475 & 498 \\
Observation & & 206 & 220 \\
\hline
\end{tabular}

Note: Figures in the parentheses are t-statistics, except for Breusch Pagan LM Test, Hausman Test, which are $p$-values. ${ }^{*}$ significant at 0.05 level $(p<0.05),{ }^{* *}$ significant at 0.1 level $(p<0.10),{ }^{* * *}$ significant at 0.01 level $(p<0.01)$.

Based on Table 6, in companies with large or above-average company categories, we obtained information that our main variable, i.e., information asymmetry, that we measure using Voltrade and PNSY, has coefficients of 2.699815 and 0.057727 , respectively, with a significance of 0.1225 and 0.8159 . Meanwhile, for companies with a small or below average category, we obtained information that the main variable of information asymmetry that we measured using Voltrade and PNSY was -0.396720 and -0.629106 , respectively, with a significance of 0.7132 and 0.0000 or significance at the 1 percent level. Based on that, we conclude that asymmetry for small companies greatly affects the cost of equity capital. Unlike the case for large companies, information asymmetry does not affect the cost of equity capital. We consider that large companies have a wide level of disclosure and have low information asymmetry, so that the cost of equity capital is not affected. Our research confirms the results of [41,57], as well as our proposed fifth hypothesis.

Table 6 also informs us that for the group with the category of large companies, the main variable of ownership structure that we measure using institutional, public and foreign ownerships has coefficients respectively at $-0.643516,-0.862899$, and -0.096452 with a significance of $0.3281,0.2094$, and 0.5170 . Meanwhile, the small company group has a coefficient of $0.000939,0.6250$, and 0.5933 , respectively, with a significance of 0.4082 , 0.6250 , and 0.5933 , respectively. Based on this, we conclude that the ownership structure of 
both large and small companies does not affect the cost of equity capital. Thus, the sixth hypothesis that we put forward cannot be proven.

The second additional test was done by dividing the companies by profit. Companies in the first group are companies with positive profits and the second group are companies with negative profits. We suspect that companies with positive profits have attractiveness to investors, so they have a low cost of equity. Table 7 below represents the test results based on this profit.

Table 7. Additional tests based on the level of profit.

\begin{tabular}{cccc}
\hline & Predictive Sign & Negative Profit & Positive Profit \\
\hline & Dependent Variable: Cost of Equity Capital (CAPM Model) \\
\hline Constant & & $-0.299210(0.5667)$ & $0.570858(0.0001)^{* * *}$ \\
Voltrade & + & $10.49489(0.0000)^{* * *}$ & $0.472193(0.2968)$ \\
PNSY & + & $-0.556977(0.0038)^{* * *}$ & $-0.520625(0.0000)^{* * *}$ \\
Inst_Own & - & $-0.000716(0.9985)$ & $0.000777(0.4346)$ \\
Pub_Own & - & $0.005303(0.2381)$ & $0.000529(0.5825)$ \\
Fore_Own & - & $0.226314(0.0913)^{* * *}$ & $-0.000381(0.2340)$ \\
Size & - & $0.076468(0.3074)$ & $-0.004395(0.8403)$ \\
Lev & + & $0.081362(0.5100)$ & $-0.016958(0.5529)$ \\
ROA & - & $-0.077545(0.7552)$ & $0.027087(0.7675)$ \\
LogSales & + & $-0.011049(0.8571)$ & $-0.008590(0.6472)$ \\
RTVOL & + & $0.297511(0.0000)^{* * *}$ & $0.611857(0.0000)^{* * * *}$ \\
F Statistic & & $18.00375(0.000000)^{* * *}$ & $23.61698(0.000000)^{* * *}$ \\
Adjusted R Square & & 0.651391 & 0.404474 \\
Sample & & 206 & 778 \\
Observation & & 92 & 334 \\
\hline
\end{tabular}

Note: Figures in parentheses are t-statistics, except for Breusch Pagan LM Test, Hausman Test, which are $p$-values ${ }^{* *}$ significant at 0.1 level $(p<0.10),{ }^{* * *}$ significant at 0.01 level $(p<0.01)$.

Based on Table 7, in the negative profit group, we obtained information on the main variable of information asymmetry that we measured using Voltrade and PNSY had coefficients of 10.49489 and -0.556977 , respectively, with a significance of 0.0000 and 0.0038 or significance at the 1 percent level. Meanwhile, in the positive profit group, the main variable of information asymmetry that we measured using Voltrade and PNSY had coefficients of 0.472193 and -0.520625 , respectively, with a significance of 0.2968 and 0.0000 , or significance at the 1 percent level. In this test we get an idea that the level of return has a significant effect on information asymmetry and the cost of equity capital. In companies with negative earnings, information asymmetry has a significant effect on the cost of equity capital. Meanwhile, companies that are classified as positive profit have relatively no effect. This means that companies with positive profits have low information asymmetry, so they do not significantly affect the cost of equity capital. It is different for companies with negative profits. These companies have high asymmetry that affects the cost of equity capital. These results also confirm our proposed seventh hypothesis.

In the ownership structure with negative earnings, we obtain information that the coefficients of institutional, public, and foreign ownerships are $-0.000716,0.005303$, and 0.226314 , respectively, with a significance of $0.9985,0.2381$, and 0.0913 , especially for significant foreign ownership at the $10 \%$ level. Meanwhile, in the ownership structure with positive profits, we obtain information that the coefficients of institutional, public, and foreign ownerships are $0.000777,0.000529$, and -0.000381 , respectively, with a significance of 0.4346 , 0.5825 , and 0.2340 . Based on this, we conclude that in companies with negative profits, foreign ownership can affect the cost of equity capital. Foreign ownership in this case can increase the cost of equity capital. Thus, the results of this additional test contradict the studies of $[29,30]$. Our research proves that at the level of companies with negative profits, entrenchment theory is more appropriate to describe the effect of foreign ownership structures and their cost of equity capital. At the same time, our research also confirms the results of $[33,34]$ and answers our proposed eighth hypothesis. Our third test divided 
companies based on their level of leverage. Companies with the above average leverage levels were grouped into the first group, and companies below the average were grouped into the second group. We suspect that companies that have a high degree of leverage will also have a high cost of equity capital. On the other hand, companies with a low level of leverage will have a low level of cost of equity capital. Table 8 represents these additional tests with leverage levels.

Table 8. Additional tests based on the leverage level.

\begin{tabular}{cccc}
\hline & Predictive Sign & Low Leverage & High Leverage \\
\hline & Dependent Variable: Cost of Equity Capital (CAPM Model) \\
\hline Constant & & $0.679623(0.0008)^{* * *}$ & $0.552578(0.0077)^{* * *}$ \\
Voltrade & + & $0.462173(0.3976)$ & $1.630450(0.0696)^{* *}$ \\
PNSY & + & $-0.401525(0.0000)^{* * *}$ & $-0.674744(0.0000)^{* * *}$ \\
Inst_Own & - & $0.000318(0.8299)$ & $0.001144(0.4225)$ \\
Pub_Own & - & $7.31 \times 10^{-5}(0.9620)$ & $0.000593(0.6450)$ \\
Fore_Own & - & $-0.000145(0.7309)$ & $-0.000405(0.4309)$ \\
Size & - & $-0.017639(0.4940)$ & $0.072146(0.0481)^{*}$ \\
Lev & + & $-0.197864(0.0460)^{*}$ & $0.008917(0.8136)$ \\
ROA & - & $0.062323(0.6548)$ & $0.012858(0.8696)$ \\
LogSales & + & $-0.007183(0.7389)$ & $-0.077583(0.0233)^{*}$ \\
RTVOL & + & $0.096581(0.0148)^{* * *}$ & $0.871984(0.0000)^{* * *}$ \\
F Statistic & & $4.769937(0.000003)^{* * *}$ & $90.71135(0.000000)^{* * *}$ \\
Adjusted R Square & & 0.130583 & 0.838335 \\
Sample & & 518 & 462 \\
Observation & & 252 & 174 \\
\hline
\end{tabular}

Note: Figures in parentheses are t-statistics, except for Breusch Pagan LM Test, Hausman Test, which are $p$-values. ${ }^{*}$ significant at 0.05 level $(p<0.05),{ }^{* *}$ significant at 0.1 level $(p<0.10),{ }^{* * *}$ significant at 0.01 level $(p<0.01)$.

Based on Table 8, for the low leverage group, we obtained information on the main variable of information asymmetry that we measured using Voltrade and PNSY and had coefficients respectively of 0.462173 and -0.401525 , with a significance of 0.3976 and 0.0000 or significance at the 1 percent level. Meanwhile, in the high leverage group, we obtained information that the main variable of information asymmetry that we measured using Voltrade and PNSY had coefficients of 1.630450 and -0.67474 , respectively. The significance of Voltrade and PNSY is 0.0696 or significant at the 10 percent level and 0.0000 or significant at the 1 percent level, respectively. Based on this, we conclude that information asymmetry affects companies with high levels of leverage. This is in line with the studies of [43-45]. Companies with a high degree of leverage also reflect a high level of risk. The results of these tests also confirm our proposed ninth hypothesis.

Table 8 also provides another main variable, i.e., ownership structure. In the low leverage group, we obtained information on ownership structure measured using institutional ownership, public ownership, and foreign ownership at coefficients of 0.000318 , $7.31 \times 10^{-5}$, and -0.000145 , respectively, with a significance of $0.8299,0.9620$, and 0.7309 . While in the high leverage group, the coefficients are $0.001144,0.000593$, and -0.000405 , respectively, with a significance of 0.4309 . Based on these results, we conclude that the ownership structure at both low and high leverage levels has no effect on the cost of equity capital. Leverage in our research sample, if it is related to ownership structure, has no effect on the size of the cost of equity capital. These results simultaneously reject our proposed tenth hypothesis.

\section{Discussion: Information Asymmetry, Ownership Structure, and Open Innovation}

This study provides strong evidence that information asymmetry and ownership structure have a significant influence on the cost of equity capital. In this study, we also succeeded in confirming agency theory, pecking order theory, Entrenchment Theory, and Interest Alignment Theory in the Indonesian context. From this point of view, we must admit that Indonesia is a developing country characterized by high information asymmetry, 
low investor protection, and the company structure is dominated by family and institutional ownership.

In the context of open innovation and digitalization, Indonesia has started to catch more open innovation and some companies may have implemented this open innovation. The examples are Kino and Tatalogram companies. These two companies can be used as good examples in the process of open innovation and digitization. Currently, open innovation is a must. Basically, the open innovation paradigm is a means or a forum for inventors in the company to partner with institutions and other companies to realize their creative ideas. The essence of innovation is how to think creatively and find new breakthroughs. Companies that innovate will continue to grow and develop. One thing that companies in Indonesia need to do in the context of open innovation is to partner with educational institutions and other companies to realize creative business ideas. This, however, is not yet apparent in Indonesia.

The paradigm of open innovation is paramount, especially in Indonesia. Moreover, Indonesia has intensified the use of information technology and digitalization in various sectors. This can minimize the condition of information asymmetry, create a vibrant stock market, and of course invite foreign investors to invest in Indonesia. This study has proven that the high level of information asymmetry and the lack of foreign investors are some of the indicators of Indonesia's high cost of equity capital compared to other ASEAN countries.

\section{Conclusions}

Our study aims to investigate how information asymmetry and ownership structure affect the cost of equity capital. For this purpose, we used data from all non-financial issuers that have consistently published financial reports for the periods of 2016-2019 on the Indonesia Stock Exchange. We collected a total of 984 observations to investigate whether the information asymmetry and ownership structure will affect the cost of equity capital.

The test results concluded that the information asymmetry we propose through Voltrade and price non-synchronization (PNSY) has a significant effect on the cost of equity capital. Meanwhile, the ownership structure that we propose through institutional ownership and foreign ownership also has a significant effect on the cost of equity capital.

For the Indonesian stock market, our research has successfully confirmed Agency Theory, Pecking Order Theory, Entrenchment Theory, and Interest Alignment Theory. We also conducted additional tests by dividing the companies by size, positive and negative profits, and degree of leverage. We conclude that for small companies, information asymmetry has an effect on the high cost of equity capital, while for large companies, there is no significant effect. Information asymmetry was also found to have a significant effect on companies with negative earnings and high levels of leverage.

Our research is expected to contribute to the debate on the existence of information asymmetry and ownership structures in relation to the cost of equity capital. We also hope that it will be a valuable input for investors in considering their investment. The rate of return and information asymmetry are especially paramount in our study as they can be used as a valuable input in considering the investment. Furthermore, from the results of this study, investors can also consider foreign ownership or institutional ownership in determining their investment. For regulators, it is important to create a healthy capital market and further encourage foreign investors to invest in Indonesia. Therefore, capital market issues in developing countries, such as lack of protection for investors and high information asymmetry, can be refuted.

Our study has some limitations. First, in line with the research objectives, we only used observations in the local context, i.e., Indonesia. Future studies can expand their research objectives by using cross-country data, so as to expand the study and make comparisons between countries. Second, from the time dimension, we only collected data from 2016 to 2019. For further studies, we suggest collecting data with a longer time dimension, so that it can expand and deepen the study. 
Author Contributions: Conceptualization, A.I.M., and D.S.; methodology, A.I.M., and D.S.; formal analysis, A.I.M., and D.S.; writing-original draft preparation, A.I.M.; writing-review and editing, A.I.M., and D.S. All authors have read and agreed to the published version of the manuscript.

Funding: This research received no external funding.

Data Availability Statement: All data of the study are publicly available. All data and materials are available upon request.

Conflicts of Interest: The authors declare no conflict of interest.

\section{References}

1. Lambert, R.A.; Leuz, C.; Verrecchia, R.E. Information asymmetry, information precision, and the cost of capital. Rev. Financ. 2012, 16, 1-29. [CrossRef]

2. $\mathrm{Hu}, \mathrm{J} . ; \mathrm{Li}, \mathrm{A} . \mathrm{Y}$; Zhang, F. Does accounting conservatism improve the corporate information environment? J. Int. Account. Audit. Tax. 2014, 23, 32-43. [CrossRef]

3. Armstrong, C.S. When Does Information Asymmetry Affect the Cost of Capital? J. Account. Res. 2011, 49, 1-39. [CrossRef]

4. Hughes, J.S.; Liu, J.; Liu, J. Information, Diversification, and Cost of Capital. Account. Rev. 2011, 82, 705-729. [CrossRef]

5. Easley, D.; Hvidkjaer, S.; O'Hara, M. Is information risk a determinant of asset returns? J. Financ. 2002, 57, 2185-2221. [CrossRef]

6. Bagnoli, M.; Watts, S.G. Conservative accounting choices. Manag. Sci. 2005, 51, 786-801. [CrossRef]

7. Ball, R. Infrastructure Requirements for an Economically Efficient System of Public Financial Reporting and Disclosure. In Brookings-Wharton Papers on Financial Services; Brookings Institution Press: Washington, DC, USA, 2001; pp. 127-169. [CrossRef]

8. Fan, Q.; Zhang, X.J. Accounting Conservatism, Aggregation, and Information Quality. Contemp. Account. Res. 2012, 29, 38-56. [CrossRef]

9. Lafond, R.; Watts, R.L. The Information Role of Conservatism. Account. Rev. 2008, 83, 447-478. [CrossRef]

10. Suijs, J. On the value relevance of asymmetric financial reporting policies. J. Account. Res. 2008, 46, 1297-1321. [CrossRef]

11. Wang, J. A model of intertemporal asset prices under asymmetric information. Rev. Econ. Stud. 1993, 60, 249-282. [CrossRef]

12. Moretti, F.; Biancardi, D. Inbound open innovation and firm performance. J. Innov. Knowl. 2020, 5, 1-19. [CrossRef]

13. Jirasakuldech, B.; Dudney, D.M. Financial disclosure, investor protection and stock market behavior: An international comparison. Rev. Quant. Financ. Account. 2011, 37, 181-205. [CrossRef]

14. Bhattacharya, U.; Daouk, D. The World Price of Insider Trading. J. Financ. 2016, 57, 75-108. [CrossRef]

15. Hail, L.; Leuz, C. International differences in the cost of equity capital: Do legal institutions and securities regulation matter? J. Account. Res. 2006, 44, 485-531. [CrossRef]

16. Hail, L.; Leuz, C. Cost of capital effects and changes in growth expectations around. J. Financ. Econ. 2009, 93, 428-454. [CrossRef]

17. Khlif, H.; Samaha, K.; Azzam, I. Disclosure, ownership structure, earnings announcement lag and cost of equity capital in emerging markets. J. Appl. Account. Res. 2015, 16, 28-57. [CrossRef]

18. Ramly, Z.; Majdi, H.; Rashid, A. Critical review of literature on corporate governance and the cost of capital: The value creation perspective. Afr. J. Bus. Manag. 2010, 4, 2198-2204.

19. Claessens, S.; Yurtoglu, B.B. Corporate governance in emerging markets: A survey. Emerg. Mark. Rev. 2013, 15, 1-33. [CrossRef]

20. Setiawan, D.; Phua, L.K. Corporate governance and dividend policy in Indonesia. Bus. Strategy Ser. 2013, 14, 135-143. [CrossRef]

21. Dakhlaoui, M.; Lajmi, A.; Rabah Gana, M. Financial Information Quality and Cost of Equity Capital: Evidence from Tunisia. J. Appl. Econ. Bus. Res. 2017, 7, 38-58.

22. Claessens, S.; Fan, J.P.H. Corporate Governance in Asia: A Survey. Int. Rev. Financ. 2002, 3, 71-103. [CrossRef]

23. La Porta, R.; Lopez-de-Silanes, F.; Shleifer, A. Corporate ownership around the world. J. Financ. 1999, 54, 471-517. [CrossRef]

24. Embong, Z.; Mohd-Saleh, N.; Hassan, M.S. Firm size, disclosure and cost of equity capital. Asian Rev. Account. 2012, 20, 119-139. [CrossRef]

25. Kong, D.; Xiao, T.; Liu, S. Asymmetric information, firm investment and stock prices. China Financ. Rev. Int. 2011, 1, 6-33. [CrossRef]

26. Jensen, M.C.; Meckling, W.H. Theory of The Firm Manajerial Behaviour, Ageny Cost and Ownership structure. J. Financ. Econ. 1976, 3, 305-360. [CrossRef]

27. Myers, S.C.; Majluf, N.S. Corporate financing and investment decisions when firms have information that investors do not have. J. Financ. Econ. 1984, 13, 187-221. [CrossRef]

28. Halov, N.; Heider, F. Capital Structure, Risk and Asymmetric Information. SSRN Electron. J. 2011, 1, 767-809. [CrossRef]

29. Gana, R.M. Ownership structure and cost of equity capital: Tunisian evidence. Int. J. Bus. Gov. Ethics 2020, 14, 96-121.

30. Lakhal, F. Les mécanismes de gouvernement d' entreprise et la publication volontaire des résultats en France. ComptabiliteControle-Audit 2006, 12, 69-92. [CrossRef]

31. Shleifer, A.; Vishny, R.W. A Survey of Corporate Governance. J. Financ. 1997, 1, 737-783. [CrossRef]

32. Dhouibi, R.; Mamoghli, C. Determinants of voluntary disclosure in Tunisian bank's reports. Res. J. Financ. Account. 2013, 4, 80-95.

33. Chu, T.; Haw, I.M.; Lee, B.B.H.; Wu, W. Cost of equity capital, control divergence, and institutions: The international evidence. Rev. Quant. Financ. Account. 2014, 43, 483-527. [CrossRef] 
34. Regalli, M.; Soana, M.-G. Corporate Governance Quality and Cost of Equity in Financial Companies. Int. J. Bus. Adm. 2012, 3, 2-16. [CrossRef]

35. Chu, T.; Haw, I.M.; Ho, S.S.M.; Zhang, X. Labor protection, ownership concentration, and cost of equity capital: International evidence. Rev. Quant. Financ. Account. 2020, 65, 1-37. [CrossRef]

36. Claessens, S.; Djankov, S.; Lang, L.H.P. The separation of ownership and control in East Asian Corporations. J. Financ. Econ. 2000, 58, 81-112. [CrossRef]

37. Faccio, M.; Lang, L.H.P. Executive stock option repricing, internal governance mechanisms, and management turnover. J. Financ. Econ. 2002, 65, 419-449. [CrossRef]

38. Skaife, H.A.; Collins, D.W.; LaFond, R. Corporate Governance and the Cost of Equity Capital. SSRN Electron. J. 2011, 26, 2006. [CrossRef]

39. Cheng, C.S.A.; Collins, D.; Huang, H.H. Shareholder rights, financial disclosure and the cost of equity capital. Rev. Quant. Financ. Account. 2006, 27, 175-204. [CrossRef]

40. Boujelbene, M.A.; Affes, H. The impact of intellectual capital disclosure on cost of equity capital: A case of French firms. J. Econ. Financ. Adm. Sci. 2013, 18, 45-53. [CrossRef]

41. Gana, R.M.; Krichen, L.A. Audit committee and external audit quality: Substitution or complementarity? Empirical evidence on euronext brussels. Int. J. Financ. Manag. Res. Dev. 2013, 3, 22-38.

42. Muiño, F.; Trombetta, M. Does graph disclosure bias reduce the cost of equity capital? Account. Bus. Res. 2009, 39, 83-102. [CrossRef]

43. Chen, K.C.W.; Chen, Z.; Wei, K.C.J. Agency costs of free cash flow and the effect of shareholder rights on the implied cost of equity capital. J. Financ. Quant. Anal. 2011, 46, 171-207. [CrossRef]

44. Lim, M.; How, J.; Verhoeven, P. Corporate ownership, corporate governance reform and timeliness of earnings: Malaysian evidence. J. Contemp. Account. Econ. 2014, 10, 32-45. [CrossRef]

45. Thijssen, P.; Iatridis, G.E. Conditional conservatism and value relevance of financial reporting: A study in view of converging accounting standards. J. Multinatl. Financ. Manag. 2016, 37-38, 48-70. [CrossRef]

46. Tessema, A.M.; Garas, S.; Tee, K. The impact of Islamic accounting standards on information asymmetry: The case of Gulf Cooperation Council (GCC) member countries. Int. J. Islamic Middle East. Financ. Manag. 2017, 10, 170-185. [CrossRef]

47. Kelly, P.J. Information efficiency and firm-specific return variation. Q. J. Financ. 2014, 4, 1450018. [CrossRef]

48. Dhaliwal, D.S.; Li, O.Z.; Tsang, A.; Yang, Y.G. Voluntary nonfinancial disclosure and the cost of equity capital: The initiation of corporate social responsibility reporting. Account. Rev. 2011, 86, 59-100. [CrossRef]

49. Ingram, M.; Margetis, S. A practical method to estimate the cost of equity capital for a firm using cluster analysis. Manag. Financ. 2010, 36, 160-167. [CrossRef]

50. Fama, E.F.; French, K.R. The Capital Asset Pricing Model: Theory and evidence. J. Econ. Perspect. 2004, 18, 25-46. [CrossRef]

51. Markowitz, H. Portfolio Selection. J. Financ. 1952, 7, 77-91. [CrossRef]

52. Sharpe, W.F. Capital Asset Price: A theory of Market Equilibrium under Condition of Risk. J. Financ. 1964, 19, 425-442. [CrossRef]

53. Klai, N.; Omri, A. Corporate Governance and Financial Reporting Quality: The Case of the Tunisian Firms. Int. Bus. Res. 2010, 4, 158-166. [CrossRef]

54. Manawaduge, A.; De Zoysa, A. The structure of corporate ownership and firm performance: Sri Lankan evidence. Corp. Ownersh Control 2013, 11, 723-734. [CrossRef]

55. Connelly, B.L.; Hoskisson, R.E.; Tihanyi, L.; Certo, S.T. Ownership as a form of corporate governance. J. Manag. Stud. 2010, 47, 1561-1589. [CrossRef]

56. Rad, S.A.; Locke, S.; Reddy, K. Global Financial Crisis and Role of Ownership Structure on Cost of Capital. Asian J. Financ. Account. 2013, 5, 396-418. [CrossRef]

57. Choi, J.H.; Lee, W.J. Association between Big 4 auditor choice and cost of equity capital for multiple-segment firms. Account. Financ. 2014, 54, 135-163. [CrossRef]

58. Gebhardt, W.R.; Lee, C.M.C.; Swaminathan, B. Toward an implied cost of capital. J. Account. Res. 2001, 39, 135-176. [CrossRef]

59. Gode, D.; Mohanram, P. Inferring the Cost of Capital Using the Ohlson_Juetter model. Rev. Account. Stud. 2003, 8, 399-431. [CrossRef]

60. Khalifa, M.; Zouaoui, H.; Ben Othman, H.; Hussainey, K. Exploring the nonlinear effect of conditional conservatism on the cost of equity capital: Evidence from emerging markets. J. Int. Account. Audit. Tax. 2019, 36, 100272. [CrossRef]

61. Aggarwal, R.; Inclan, C.; Leal, R. Volatility in Emerging Stock Markets. J. Financ. Quant. Anal. 1999, 34, 33. [CrossRef] 